\title{
RARE EARTH ELEMENTS ENRICHMENT OF FIXED-BED COAL ASH FROM A PILOT PLANT GASIFICATION BY PHYSICAL METHODS
}

\author{
PENINGKATAN KANDUNGAN LOGAM TANAH JARANG (LTJ) ABU \\ BATUBARA SISTEM UNGGUN DIAM SKALA PILOT PLANT \\ MENGGUNAKAN METODE SECARA FISIK
}

\author{
SUGANAL \\ R\&D Centre for Mineral and Coal Technology \\ Jalan Jenderal Sudirman 623 Bandung 40211 \\ Ph. (+6222) 6030483, Fax. (+6222) 6003373 \\ e-mail: suganal@esdm.go.id
}

\begin{abstract}
Research and development regarding coal gasification at a pilot scale in Palimanan has been conducted since 2008. Besides the gas product, attention on chemical element identification within the bottom ash is also necessary. The aim is to implement the research and development activities in integrating coal utilization processes by zero waste. The most important content within the coal ash is the precious metal elements, namely the rare earth elements. Characterization on the fixed bed gasification coal ash from Palimanan pilot plant shows that the ash contains the rare earth elements (REE) such as cerium, lanthanum, samarium, neodymium, praseodymium, europium, gadolinium, dysprosium, and yttrium. Its bearing minerals include zircon silicate minerals $\left(\mathrm{ZrSiO}_{4}\right)$ and monazite-Ce $\left(\mathrm{CePO}_{4}\right)$. The total content of the rare earth elements is $77.85 \mathrm{ppm}$. In this work, the rare earth elements concentration successfully increased using shaking table and magnetic separator methods. It reached up to $217 \mathrm{ppm}$. However, the shaking table was more effective to increase the concentration. Approximately two times concentrates were achieved, while no significant results derived from the magnetic separator process.
\end{abstract}

Keywords: coal ash, gasification, rare earth elements, monazite, shaking table

\begin{abstract}
ABSTRAK
Penelitian dan pengembangan gasfikasi batubara skala pilot plant di Palimanan telah berlangsung sejak 2008. Di samping perhatian pada produk gas, identifikasi unsur-unsur kimia bernilai tinggi pada buangan proses gasifikasi batubara berupa abu dasar (bottom ash) perlu dilakukan. Upaya tersebut merupakan langkah penerapan hasil kegiatan penelitian dan pengembangan terpadu menuju proses pemanfaatan batubara tanpa buangan (zero waste). Abu batubara mengandung logam berharga yang tergabung dalam kelompok logam tanah jarang. Hasil identifikasi menunjukkan abu batubara sisa proses gasifikasi unggun diam pada pilot plant grasifikasi batubara Palimanan mengandung logam tanah jarang (LTJ) terdiri atas serium, lantanum, samarium, neodimium, praseodimium, europium, gadolinium, disprosium dan itrium dengan mineral pembawanya berupa zircon silikat $\left(\mathrm{ZrSiO}_{4}\right)$ dan monasit-Ce $\left(\mathrm{CePO}_{4}\right)$. Kadar total logam tanah jarang yang terkandung adalah 77,85 ppm. Peningkatan kadar logam tanah jarang secara fisika menggunakan meja goyang dan pemisah magnet dapat meningkatkan logam tersebut sampai 217 ppm, namun dari kedua metode tersebut hanya meja goyang yang paling efektif untuk meningkatkan kadar logam tanah jarang sampai dua kali lipat yang terdapat pada aliran konsentratnya, sedangkan peningkatan dengan pemisah magnet tidak menunjukkan kuantitas kadar berarti.
\end{abstract}

Kata kunci: Abu gasifikasi batubara, unsur LTJ, monasit, shaking table logam tanah jarang 


\section{INTRODUCTION}

Research and development of coal gasification at the pilot scale the Centre of Coal Technology, Palimanan, West Java since 2008. One of the R\&D focus is to develop the coal gas for electricity purposes, especially for a dual fuel system in power plant and fuel gas in the gas engine system. Until now, the research only focused on producing coal gas and its utilization in the power plant. Yet, the identification of its chemical waste composition from the coal gasification process, especially the bottom ash, is necessary to be studied as an effort to implement the R\&D activities that lead to the zero waste of coal utilization (Suganal, 2017).

Coal gasification is a process to convert the coal into a gas. The obtained gas then can be used as a fuel or as raw material for chemical industries. There are four systems in a gasification process, one of them is a fixed bed coal gasification. This system uses a granular feed and the bed has a relatively a constant height. The coal is fed through the feeding hole that is located on the upper side of the reactor. The coal bed then moves down slowly and simultaneously with gasification reaction (Elliott, 1981). A chemical reaction in coal gasification involves fission and oxidation reactions of hydrocarbon compounds to produce gases such as $\mathrm{CO}, \mathrm{H}_{2}, \mathrm{CO}_{2}$, and $\mathrm{H}_{2} \mathrm{O}$. Some other important compounds are $\mathrm{H}_{2} \mathrm{~S}$, sulfur and carbon compounds, $\mathrm{NH}_{3}$, light hydrocarbon, and weight hydrocarbon including tar (Speight, 2013).

Chemical reactions that take place during coal gasification process served in equation 1 to 9 (Yermagambet et al., 2016):

$$
\begin{array}{ll}
\mathrm{C}+\mathrm{O}_{2}=\mathrm{CO}_{2} & \Delta \mathrm{H}=-404,7 \mathrm{~kJ} / \mathrm{mol}(1) \\
2 \mathrm{C}+\mathrm{O}_{2}=2 \mathrm{CO} & \Delta \mathrm{H}=-246,4 \mathrm{~kJ} / \mathrm{mol}(2) \\
2 \mathrm{CO}+\mathrm{O}_{2}=2 \mathrm{CO}_{2} & \Delta \mathrm{H}=-567,3 \mathrm{~kJ} / \mathrm{mol}(3) \\
\mathrm{CO}_{2}+\mathrm{C}=2 \mathrm{CO} & \Delta \mathrm{H}=161 \mathrm{~kJ} / \mathrm{mol}(4) \\
\mathrm{C}+2 \mathrm{H}_{2}=\mathrm{CH}_{4} & \Delta \mathrm{H}=-83,8 \mathrm{~kJ} / \mathrm{mol}(5) \\
\mathrm{C}+\mathrm{H}_{2} \mathrm{O}=\mathrm{CO}+\mathrm{H}_{2} & \Delta \mathrm{H}=118,5 \mathrm{~kJ} / \mathrm{mol}(6) \\
\mathrm{C}+2 \mathrm{H}_{2} \mathrm{O}=\mathrm{CO}_{2}+2 \mathrm{H}_{2} & \Delta \mathrm{H}=16,3 \mathrm{~kJ} / \mathrm{mol}(7) \\
\mathrm{CO}+3 \mathrm{H}_{2}=\mathrm{CH}_{4}+\mathrm{H}_{2} \mathrm{O} & \Delta \mathrm{H}=-206,7 \mathrm{~kJ} / \mathrm{mol}(8) \\
\mathrm{CO}+\mathrm{H}_{2} \mathrm{O}=\mathrm{CO}_{2}+\mathrm{H}_{2} & \Delta \mathrm{H}=-42,4 \mathrm{~kJ} / \mathrm{mol}(9)
\end{array}
$$

Coal gasification process generates ash as a by-product, commonly called coarse ash, which is a non-combustible inorganic compound, solid material, inert, 4-75 $\mathrm{mm}$ in size, usually containing 4-7\% unburnt carbon (Ginster and Matjie, 2005). The ash generally composed of minerals such as quartz, hematite, mullite, and some of them containing trace elements such as rear earth elements (REE).

REE is a group of 15 elements lanthanide (atomic number 57-71) from lanthanum (atomic number 57) to lutetium (atomic number 71), and two elements of transition elements (scandium dan yttrium). REE is divided into two groups based on the variation of ion radius and electron structures (Endang Suwargi, Pardiarto and Ishlah, 2010; Zhang, Groppo and Honaker, 2015):

a. Light REE, sub-class cerium (from lanthanum to europium);

b. Weight REE, sub-class yttrium (from gadolinium to lutetium and yttrium).

The name and symbol of REE written in Table 1, while the position in the periodic system shown in Figure 1.

The increase of REE utilization started since the late 1960s when the development of process technology and commercial-scale purification has been achieved. The use of the elements have been expanded in many fields such as health, military, energy, permanent magnets, informatics, batteries including oil refining (Zhang, Groppo and Honaker, 2015).

According to the US Patent, extraction of REE from coal ash can be conducted by magnetic separation followed by leaching with nitrate acid mixed with tributyl phosphate and kerosene at $90^{\circ} \mathrm{C}$. The final step is ion exchange to separate the metals non-REE from the leached (Sahoo et al., 2016).

The use of coal in Indonesia power plant will increase significantly in 2015 up to the capacity of $289.7 \mathrm{GW}$, as the consequence of the huge number of coal resources in Indonesia and to produce low-cost electricity (Fitriana et al., 2017). Until now, the Indonesia power plant is still dominated by the pulverized coal combustion system. However, in some areas, the use of coal gasification system has been applied. 
Table 1. Name dan symbol of REE

\begin{tabular}{cccccc}
\hline Symbol & Element name & Symbol & Element name & Symbol & Element name \\
\hline $\mathrm{Sc}$ & Scandium & $\mathrm{Pm}$ & Promethium & $\mathrm{Ho}$ & Holmium \\
$\mathrm{Y}$ & Yttrium & $\mathrm{Sm}$ & Samarium & $\mathrm{Er}$ & Erbium \\
$\mathrm{La}$ & Lanthanum & $\mathrm{Eu}$ & Europium & $\mathrm{Tm}$ & Thulium \\
$\mathrm{Ce}$ & Cerium & $\mathrm{Gd}$ & Gadolinium & $\mathrm{Yb}$ & Ytterbium \\
$\mathrm{Pr}$ & Praseodymium & $\mathrm{Tb}$ & Terbium & $\mathrm{Lu}$ & Lutetium \\
$\mathrm{Nd}$ & Neodymium & $\mathrm{Dy}$ & Dysprosium & - & - \\
\hline
\end{tabular}

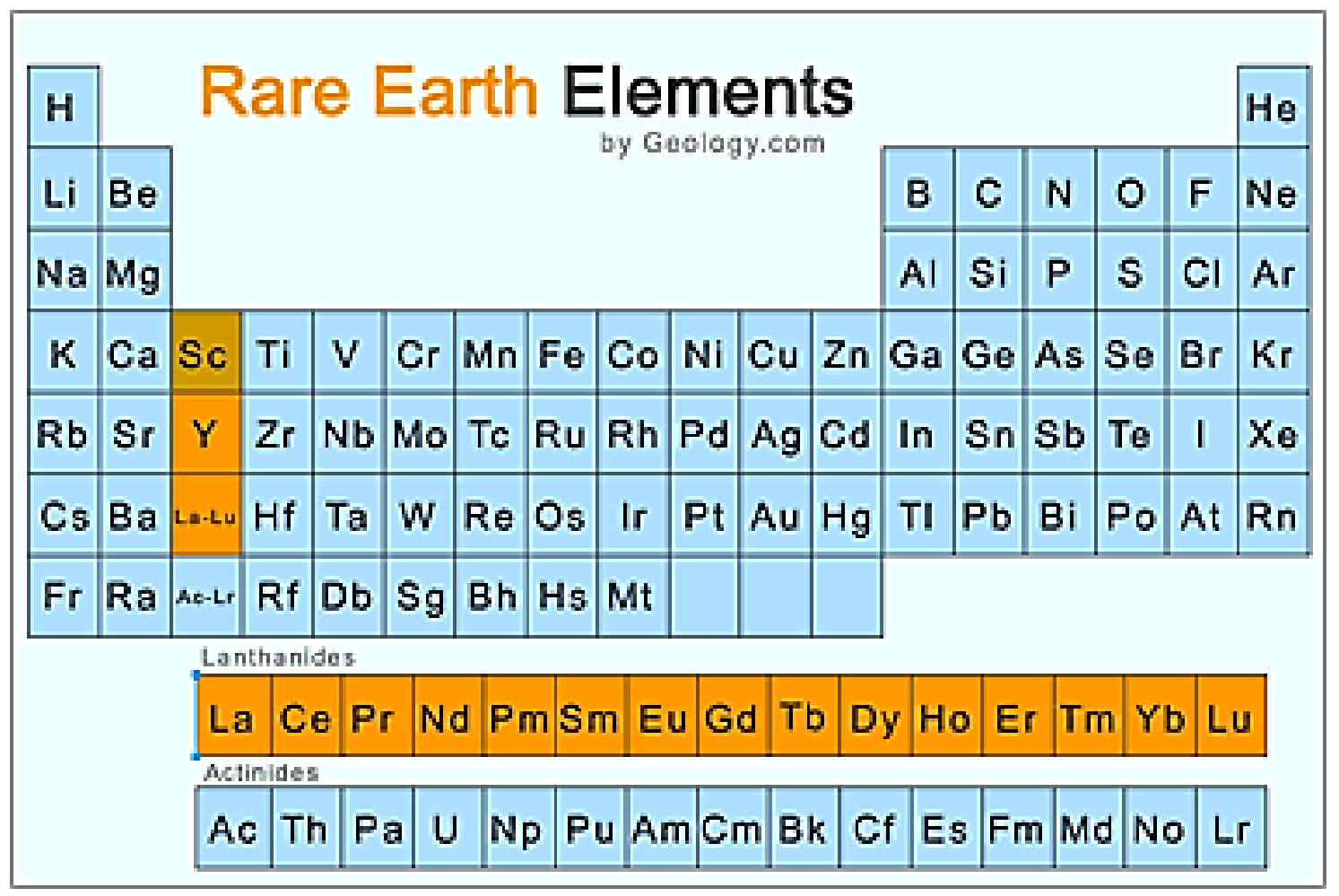

Figure 1. REE in periodic table system (Long et al., 2018)

The application of coal gasification as an alternative fuel for the power plant is predicted to increase, especially for the small-scale power plant. Based on the studies, the system also releases the coal ash (solid waste) contains several REEs (Hower et al., 2016). By mastering the REE separation process from the impurities within the coal ash, no awadays the coal ash is categorized as one of the REE resources (Zhang, Groppo and Honaker, 2015).

The aims to identify the REE content within the coal ash from gasification proses at Palimanan pilot plant, West Jawa, and to increase its concentration by physical methods.

\section{METHODOLOGY}

Samples of coal gasification ash were taken from the coal gasification fixed bed pilot plant. Figure 2 shows a series of fixed bed gasification equipment. Sample preparation was carried out referring to the ASTM in term of getting the representative samples to be analyzed at the Testing Laboratory of Coal and Mineral at the Research and Development Center for Mineral and Coal Technology and other similar laboratories at other related institutions. The characterization was conducted using $X$-ray diffraction (XRD), $X$-ray fluorescence (XRF), scanning electron microscope (SEM), atomic adsorption spectroscopy (AAS), inductively coupled plasma (ICP), and equipments of coal proximate and ultimate analysis. Then the 
ash was physically concentrated that based on density and magnetism differences using shaking table and magnetic separator. The silicate minerals, especially quartz $\left(\mathrm{SiO}_{2}\right)$, has a density of $2.7 \mathrm{~g} / \mathrm{cm}^{3}$, the magnetite 5.15 $\mathrm{g} / \mathrm{cm}^{3}$, alumina silicate $\left(\mathrm{Al}_{2} \mathrm{O}_{3}, \mathrm{SiO}_{2}\right) 3.69 \mathrm{~g} /$ $\mathrm{cm}^{3}$ while the coal ash itself has a density of about $2.23 \mathrm{~g} / \mathrm{cm}^{3}$ (Suganal, Umar and Mamby, 2018). The light minerals move to the tailing part while the heavy one stays on the concentrate part. Each concentration in the form of concentrate, middling and tailing were analyzed using ICP. Furthermore, the output of shaking table which is containing high REE then entered a magnetic separation process using a magnetic separator.

\section{RESULT AND DISCUSSIONS}

\section{Distribution and Composition of REE in Coal Gasification Ash}

Table 2 shows the proximate analysis of gasification coal ash and gasification coal feed. The analysis shows that the coal gasification process did not work properly in converting the hydrocarbons from a solid coal into a gas that will be used as a fuel in the generator (Sodikin et al., 2016). The fixed carbon content is read still high $(39.57 \% \mathrm{adb})$ and the content of carbon (C) detected by SEM amounting to $58.26 \%$ (Table 5 and
Table 6). Results of the ultimate analysis showed the relatively high carbon element namely at $42.37 \%$ (adb) as seen in Table 2 .

Coal gasification process usually produces a by-product in the form of granular charcoal; improper gasified coal. Char will cause problems in the solid effluent in a dumping area because it can oxidize to form toxic gases. However, by developing a new generation of the gasification process, the waste char is relatively rare (Pomykała and Mazurkiewicz, 2015). Ye, Oh and Ryu (2015) reported that coal gasification process often obtained a granular charcoal, as a result of the improper reaction of fixed residual carbon. Gasification reaction of carbon element in the fixed carbon with a gas reactant such as $\mathrm{CO}_{2}$, $\mathrm{H}_{2} \mathrm{O}$ or $\mathrm{H}_{2}$ is relatively more difficult than the reaction between the carbon element in the volatile matter (Hosseini, 2015). An indication of optimal coal conversion into a fuel gas or thermal energy through direct combustion or gasification can be seen from the ash content that should reach> $90 \%$ and the fixed carbon content $<5 \%$. As a comparison, the bottom ash of coal combustion for boiler fuel at a textile factory in Bandung still has a high fixed carbon content, around $32-45 \%$. It shows that the coal combustion process was improper and the energy recovery was not maximized (Suprapto, 2009).

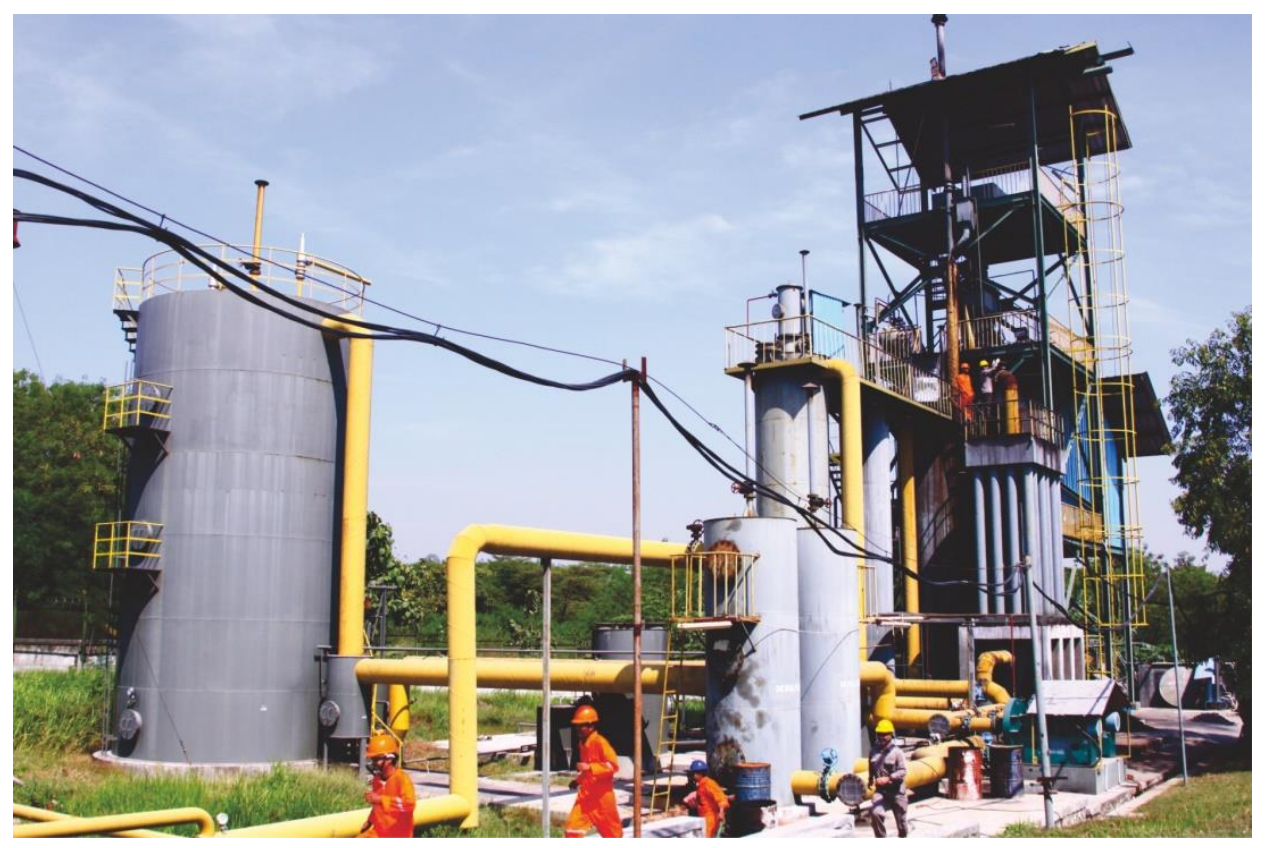

Figure 2. A fixed bed system of coal gasification unit in Palimanan 


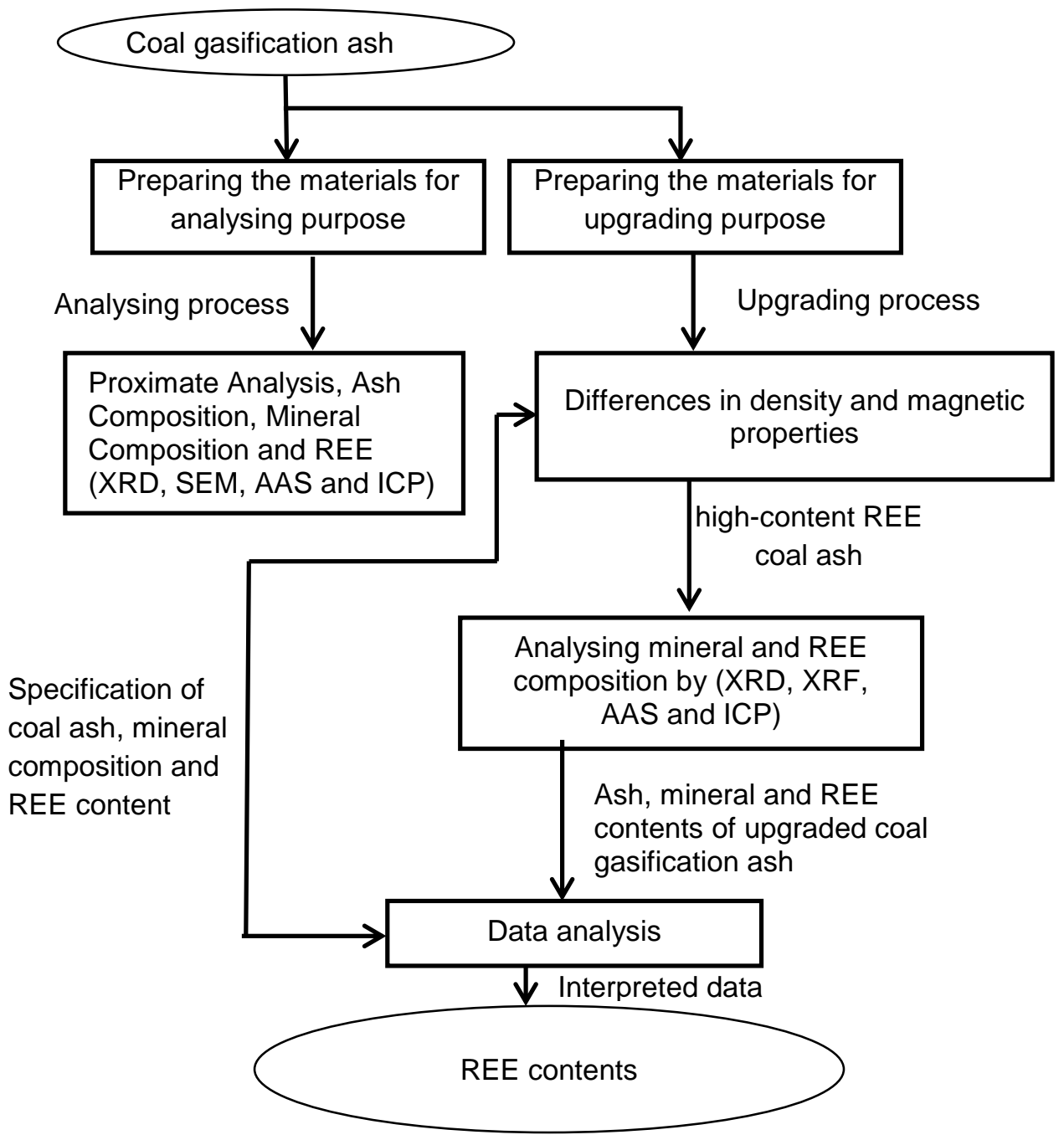

Figure 3. Flowchart of REE characterization and enrichment from coal gasification ash

Table 2. Proximate and ultimate analyses of coal ash and feed

\begin{tabular}{lcrr}
\hline \multirow{2}{*}{ No. } & Parameter & \multicolumn{2}{c}{ Value (\%, adb) } \\
\cline { 3 - 4 } & PROXIMATE & Coal ash & Coal feed \\
1 & Moisture & 4.57 & 17.19 \\
2 & Ash & 51.24 & 3.01 \\
3 & Volatile matter & 4.62 & 38.6 \\
4 & Fixed carbon & 39.57 & 41.16 \\
\hline & ULTIMATE & & 0.17 \\
5 & Sulphure & 0.27 & 61.08 \\
6 & Carbon & 42.37 & 6.40 \\
7 & Hydrogen & 0.94 & 0.84 \\
9 & Nitrogen & 0.22 & 28.50 \\
\hline
\end{tabular}

Analyzing the mineral and REE contents in the coal ash was conducted using XRD, SEM, AAS, and ICP as shown in Table 3 to 8 and Figure 4 to 6 . Based on Figure 4 and Table 3, the presence of REE minerals such as monazite, zircon, and xenotime are not detected in the ash gasification. The reason is due to those minerals are relatively small, so the upgrading process is needed at the first step (Suganal, Suratman and Kusnawan, 
2016). The ash composition in Table 4 also do not show any REE compounds.

SEM analysis in Table 5 and 6 shows the existence of REE elements or compounds within the coal gasification ash. The detected compounds are only neodymium $\left(\mathrm{Nd}_{6} \mathrm{O}_{12}\right)$ and europium oxides $\left(\mathrm{Eu}_{2} \mathrm{O}_{3}\right)$. More detailed detection was carried out by ICP analysis as listed in Table 7. The number of detected elements are up to 9 .
Differences in chemical composition of ash analysis (Table 4 and 5) is due to the gasification ash was burned in advance to get the high content non combustable ash so that the carbon element has been burned out. A high carbon quantity in the coal gasification ash shown in Table 5 and 6 reveal inefficient gasification process (Silva et al., 2010).

Table 3. Mineral content of coal gasification ash

\begin{tabular}{cllc}
\hline No. & \multicolumn{1}{c}{ Mineral composition } & \multicolumn{1}{c}{ Compound } & Chemical formula \\
\hline 1 & Quartz & Silicon oxide & $\mathrm{SiO}_{2}$ \\
2 & Opal & Silica hydrate & $\mathrm{SiO}_{2} . \mathrm{xH}_{2} \mathrm{O}$ \\
3 & Magnetite & Iron (III) oxide & $\mathrm{Fe}_{3} \mathrm{O}_{4}$ \\
4 & Mullite & Aluminum silicate & $\mathrm{Al}_{6} \mathrm{Si}_{2} \mathrm{O}_{13}$ \\
5 & Albite & Sodium aluminum silicate & $\mathrm{NaAlSi}_{3} \mathrm{O}_{8}$ \\
6 & Hematite & Ferro oxide & $\mathrm{Fe}_{2} \mathrm{O}_{3}$ \\
\hline
\end{tabular}

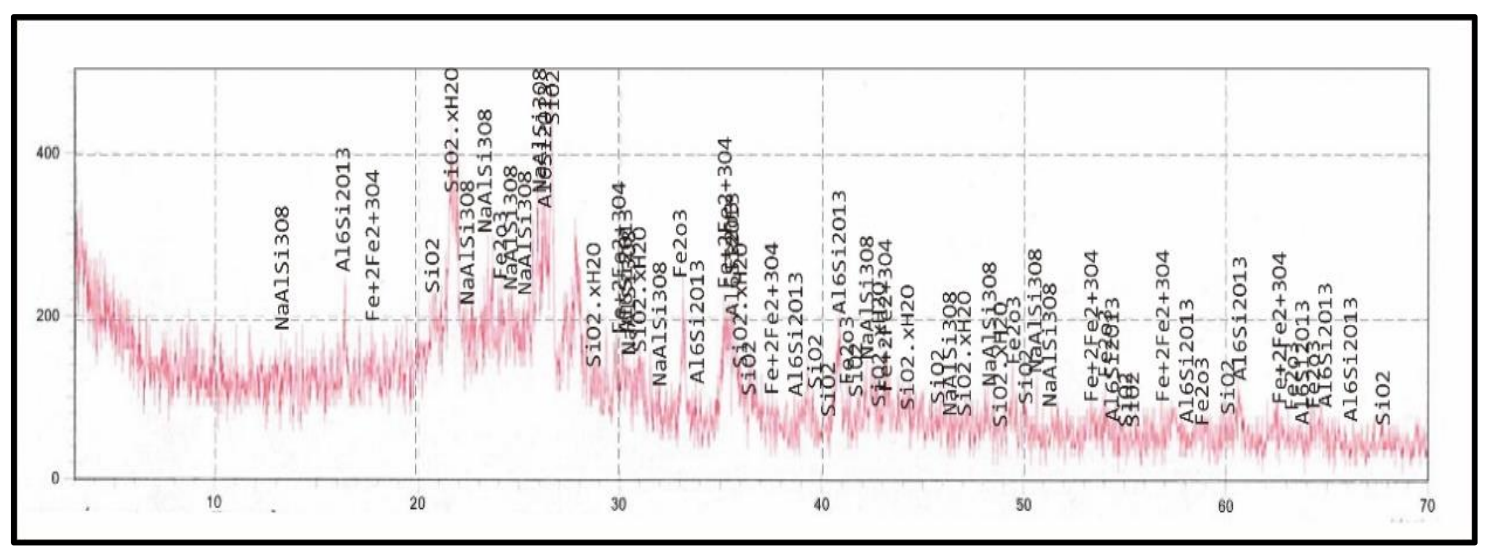

Figure 4. XRD analysis of coal gasification ash.

Table 4. Coal ash composition

\begin{tabular}{ccc}
\hline No. & Compounds/Chemical formula & $\mathrm{Wt} \%$ \\
\hline 1 & $\mathrm{SiO}_{2}$ & 47.93 \\
2 & $\mathrm{Al}_{2} \mathrm{O}_{3}$ & 30.33 \\
3 & $\mathrm{Fe}_{2} \mathrm{O}_{3}$ & 8.87 \\
4 & $\mathrm{~K}_{2} \mathrm{O}$ & 0.70 \\
5 & $\mathrm{Na}_{2} \mathrm{O}$ & 0.95 \\
6 & $\mathrm{CaO}$ & 6.92 \\
7 & $\mathrm{MgO}$ & 1.88 \\
8 & $\mathrm{TiO}_{2}$ & 1.19 \\
9 & $\mathrm{MnO}_{1}$ & 0.029 \\
10 & $\mathrm{P}_{2} \mathrm{O}_{5}$ & 0.60 \\
11 & $\mathrm{SO}_{3}$ & 0.36 \\
12 & $\mathrm{H}_{2} \mathrm{O}$ & 0.009 \\
13 & $\mathrm{LOI}^{2}$ & 0.52 \\
\hline
\end{tabular}


Rare Earth Elements Enrichment of Fixed-Bed Coal Ash from a Pilot Plant ... Suganal

Table 5. Chemical compounds in the coal ash

\begin{tabular}{clcc}
\hline No. & Compound name & Chemical formula & wt\% \\
\hline 1 & Carbon & $\mathrm{C}$ & 58.26 \\
2 & Corundum & $\mathrm{Al}_{2} \mathrm{O}_{3}$ & 13.40 \\
3 & Silica & $\mathrm{SiO}_{2}$ & 16.02 \\
4 & Difosfor pentaoxide & $\mathrm{P}_{2} \mathrm{O}_{5}$ & 1.23 \\
5 & Calcium Oxide & $\mathrm{CaO}$ & 3.19 \\
6 & Iron Oxide & $\mathrm{FeO}$ & 7.5 \\
7 & Neodymium Oxide & $\mathrm{Nd}_{6} \mathrm{O}_{12}$ & 0.01 \\
8 & Europium Oxide & $\mathrm{Eu}_{2} \mathrm{O}_{3}$ & 0.39 \\
\hline \multicolumn{4}{c}{ Total } \\
\hline
\end{tabular}

Table 6. Elements in coal gasification ash (SEM X-ray mapping)

\begin{tabular}{clcc}
\hline No. & \multicolumn{1}{c}{ Element } & Chemical formula & wt\% \\
\hline 1 & Carbon & $\mathrm{C}$ & 58.26 \\
2 & Oxygen & $\mathrm{O}$ & 18.16 \\
3 & Aluminum & $\mathrm{Al}$ & 7.09 \\
4 & Silica & $\mathrm{Si}$ & 7.49 \\
5 & Phosphor & $\mathrm{P}$ & 0.54 \\
6 & Calcium & $\mathrm{Ca}$ & 2.28 \\
7 & Iron & $\mathrm{Fe}$ & 5.83 \\
8 & Neodymium & $\mathrm{Nd}$ & 0.01 \\
9 & Europium & $\mathrm{Eu}$ & 0.34 \\
\hline \multicolumn{5}{c}{ Total } \\
\hline
\end{tabular}
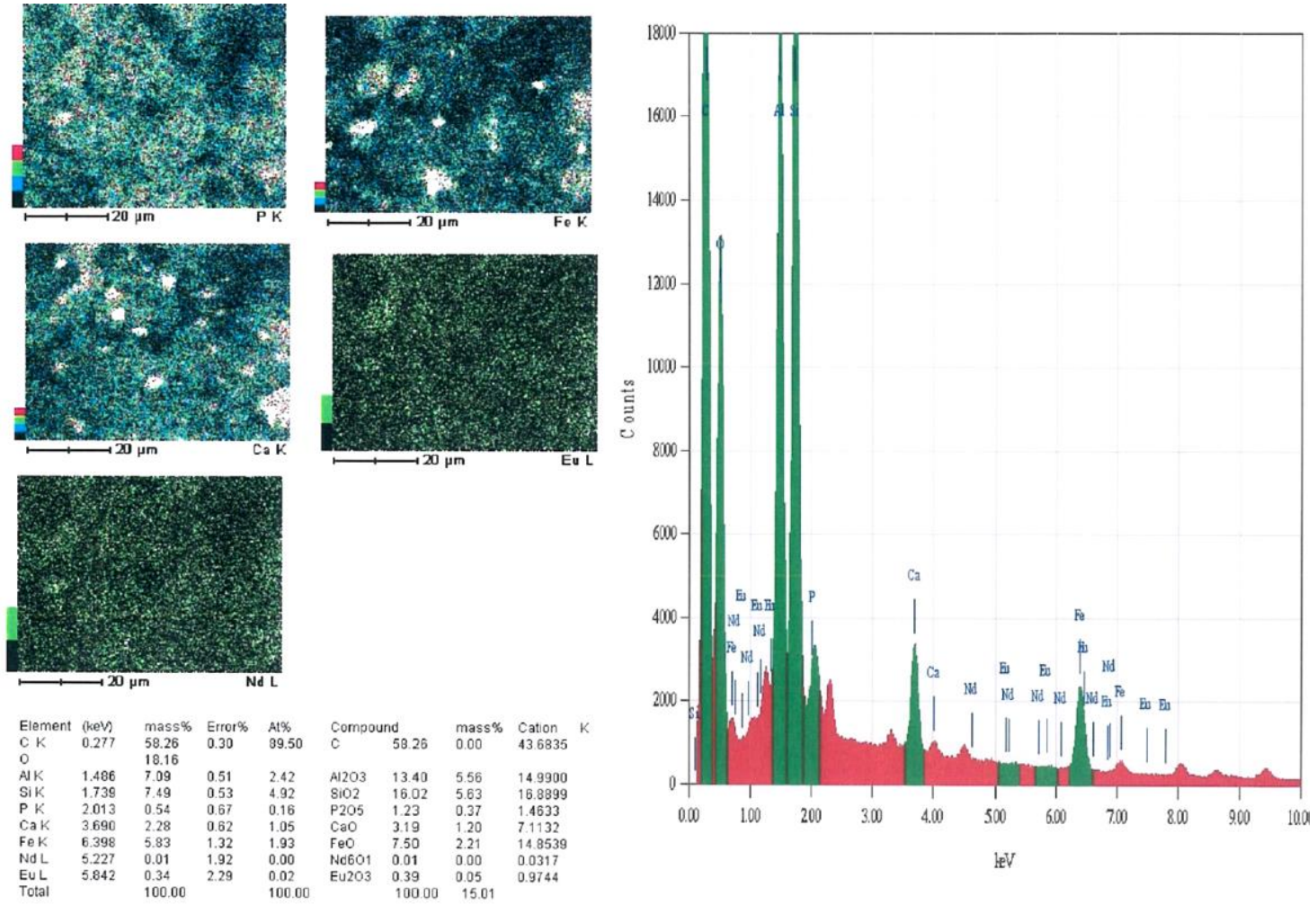

Figure 5. X-ray mapping of SEM-EDX analysis for coal gasification ash 
Table 7. REE content in the coal ash

\begin{tabular}{clcr}
\hline No. & \multicolumn{1}{c}{ REE } & $\begin{array}{c}\text { Chemical } \\
\text { formula }\end{array}$ & $\begin{array}{c}\text { Content, } \\
\text { ppm }\end{array}$ \\
\hline 1 & Cerium & $\mathrm{Ce}$ & 16.3504 \\
2 & Lanthanum & $\mathrm{La}$ & 11.1346 \\
3 & Samarium & $\mathrm{Sm}$ & 9.139 \\
4 & Neodymium & $\mathrm{Nd}$ & 6.9738 \\
5 & Praseodymium & $\mathrm{Pr}$ & 7.6671 \\
6 & Europium & $\mathrm{Eu}$ & 2.1686 \\
7 & Gadolinium & $\mathrm{Gd}$ & 7.6059 \\
8 & Dysprosium & $\mathrm{Dy}$ & 4.5419 \\
9 & Yttrium & $\mathrm{Y}$ & 12.2715 \\
\hline \multicolumn{3}{c}{ Total rare earth } & 77.8527 \\
\hline
\end{tabular}

Zhang, Groppo and Honaker (2015) reported that the REE amount within coal ash in several countries including China, USA, Turkey and Korea are as follows: $\mathrm{Ce}=23 \mathrm{ppm} ; \mathrm{La}=11$ $\mathrm{ppm} ; \mathrm{Sm}=1.6 \mathrm{ppm} ; \mathrm{Nd}=12 \mathrm{ppm} ; \mathrm{Pr}=3.5$ ppm; $\mathrm{Eu}=0.47 \mathrm{ppm} ; \mathrm{Gd}=2.7 \mathrm{ppm} ; \mathrm{Dy}=2.1$ $\mathrm{ppm}$ and $\mathrm{Y}=8,4 \mathrm{ppm}$. Referring to the data, most of the REE contents of Indonesian coal ash are high (Sm, Pr, Eu, Gd, Dy, and Y). This potential will assist Indonesia government on renewable energy program and health as well.

To detect the REE-bearing minerals from coal ash, it has been conducted enrichment process using shaking table and magnetic separation. The results detected monazite and zircon as shown in Figure 6 and Table 8. Monazite is a carrier of $\mathrm{La}, \mathrm{Ce}, \mathrm{Pr}, \mathrm{Nd}$, and Sm (Roth et al., 2017).

\section{Enrichment Process of REE Content from Coal Gasification Ash}

Based on the ash analysis as listed in Table 4 , some compounds in coal ash are detected. The analysis results are used to determine the stages of the enrichment process of the
REE content. The enrichment was conducted using a shaking table and magnetic separator.

The process of shaking table held on the deck slope inclination angle of $3^{\circ}$ and water flow rate of 14 liters/minute. The results are divided into three fractions, namely concentrate, middling and tailing. The composition ash in Table 4 shows the silica content around $47.93 \%$, hematite $\left(\mathrm{Fe}_{2} \mathrm{O}_{3}\right) 8.87 \%$, and alumina $\left(\mathrm{Al}_{2} \mathrm{O}_{3}\right) 30.33 \%$. Based on the composition of the dominance silica and alumina, the density of silica is $2.65 \mathrm{~g} / \mathrm{cm}^{3}$, alumina $3.95 \mathrm{~g} / \mathrm{cm}^{3}$ while the density of REE ranges from 4 to 8.5 $\mathrm{g} / \mathrm{cm}^{3}$, so the REE is predicted to be concentrated in the concentrate. Results of the shaking table process were analyzed using the ICP (Table 9 and Figure 6). In Figure 7, it looks that the REE content in the concentrate fraction is generally higher than that in the middling or tailing fraction. When compared to the REE content within the feed of the tabling process, generally the REE content increased almost two times, especially in the concentrates and middling fractions.

The parameter for evaluating the success of tabling known as concentration criteria (CC). If the value $>2.5$ then the separation would be run easily. The formula of concentration criteria is presented as follows (Rodliyah, 2017):

$$
\text { Concentration Criteria }(C C)=\frac{D h-D f}{D I-D f}
$$

Dh = heavy mineral density

DI = light mineral density

Df = density of fluid used

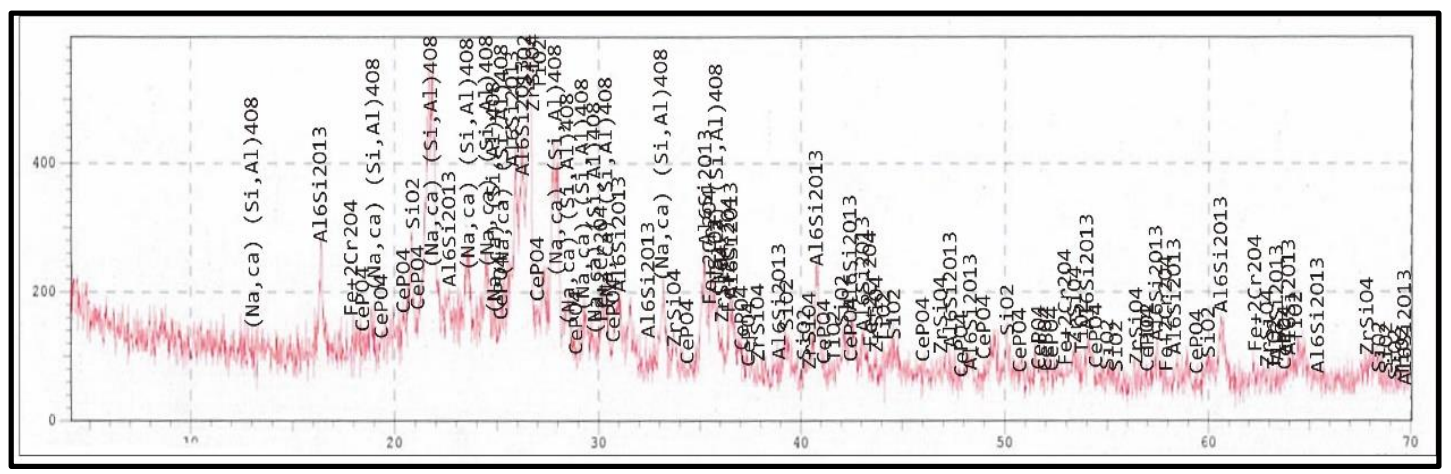

Figure 6. XRD analysis of non-magnetic concentrated materials 
Table 8. Mineral content of non-magnetic concentrated materials

\begin{tabular}{clc}
\hline No. & \multicolumn{1}{c}{ Minerals } & Chemical formula \\
\hline 1 & Silica & $\mathrm{SiO}_{2}$ \\
2 & Aluminum Silicate & $\mathrm{Al}_{6} \mathrm{Si}_{2} \mathrm{O}_{13}$ \\
3 & Zirconium Silicate & $\mathrm{ZrSiO}_{4}$ \\
4 & Sodium Calcium, Aluminum Silicate & $(\mathrm{Na}, \mathrm{Ca})(\mathrm{Si}, \mathrm{Al}){ }_{4} \mathrm{O}_{8}$ \\
5 & Titanium Oxide & $\mathrm{TiO}_{2}$ \\
6 & Monazite-Ce & $\mathrm{CePO}_{4}$ \\
7 & Chromite & $\mathrm{Fe}+2 \mathrm{Cr}_{2} \mathrm{O}_{4}$ \\
\hline
\end{tabular}

Table 9. REE content after the tabling process

\begin{tabular}{clcrrr}
\hline \multirow{2}{*}{ No. } & \multirow{2}{*}{ REE } & \multirow{2}{*}{ Symbol } & \multicolumn{3}{c}{ REE quantities (ppm) } \\
\cline { 4 - 6 } & & Concentrate & Middling & \multicolumn{1}{c}{ Tailing } \\
\hline 1 & Cerium & Ce & 35.3128 & 26.2203 & 16.1114 \\
2 & Lanthanum & La & 32.2062 & 27.0062 & 14.7688 \\
3 & Samarium & Sm & 23.1723 & 15.3241 & 13.5559 \\
4 & Neodymium & Nd & 15.6375 & 4.3549 & 9.3954 \\
5 & Praseodymium & $\mathrm{Pr}$ & 23.8683 & 16.8464 & 10.3591 \\
6 & Europium & $\mathrm{Eu}$ & 3.1424 & 1.3231 & 2.003 \\
7 & Gadolinium & $\mathrm{Gd}$ & 19.2251 & 15.6779 & 9.6558 \\
8 & Dysprosium & $\mathrm{Dy}$ & 13.4482 & 8.1356 & 3.7478 \\
9 & Yttrium & $\mathrm{Y}$ & 22.5299 & 22.4925 & 14.4362 \\
\hline & Total REE & & 188.5427 & 137.381 & 94.0334 \\
\hline
\end{tabular}

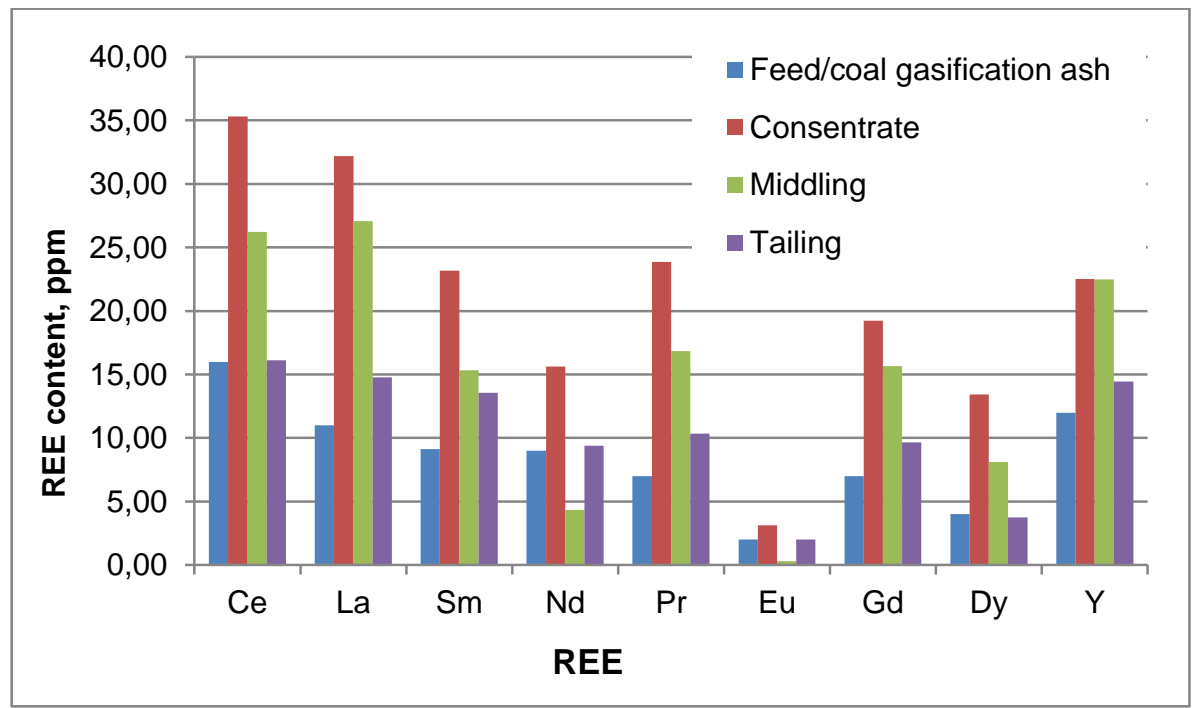

Figure 7. REE content after the tabling process

The research of coal ash from the Ombilin power plant reported that the REE-bearing mineral in the fly ash from that power plant is monazite (Suganal, Umar and Mamby, 2018). According to the CC value of monazite and silica (3.0) that is higher than that of the minimum limit of the $\mathrm{CC}$, the content increase of $\mathrm{La}, \mathrm{Ce}, \mathrm{Pr}, \mathrm{Sm}$, and $\mathrm{Nd}$ are due to its association in monazite as shown in Table 9 and Figure 7.

\section{Enrichment of the REE content using a magnetic separator}

The used of the magnetic field is 2,250 gauss. This process aims to separate the magnetic and non-magnetic materials. The REE is a paramagnetic material that can be attracted by the cylinder magnet. The REE would be more concentrated in the magnetic products than non-magnetic ones. After obtaining the desired products either 
magnetic and non-magnetic, sampling was performed on each fraction to be analyzed for its REE content and ash composition using ICP, AAS, XRF, and XRD. Results of the analysis are listed in Figure 8 and 9 as well as Table 10 and 11.

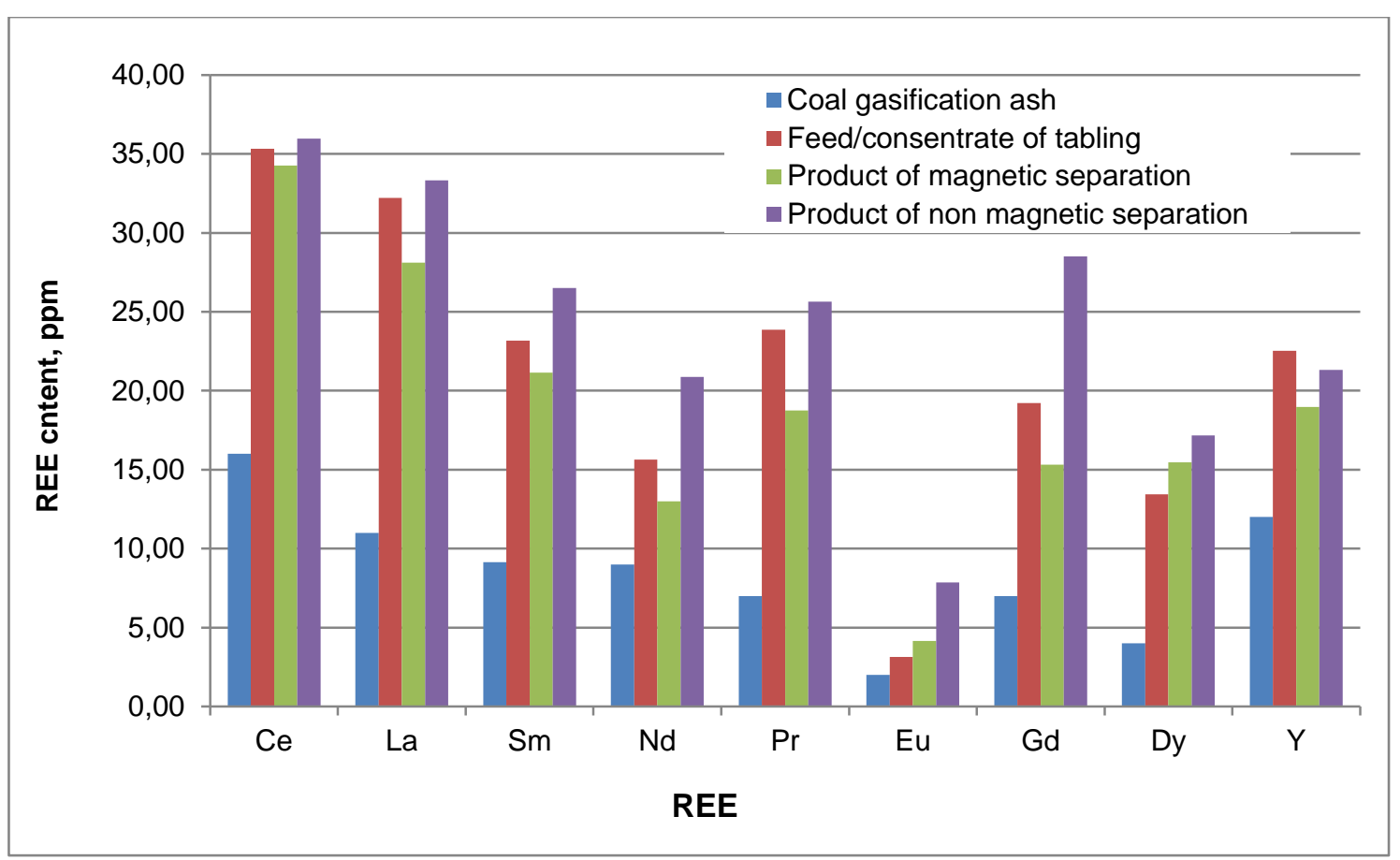

Figure 8. REE content in tabling consentrate derived from magnetic separation

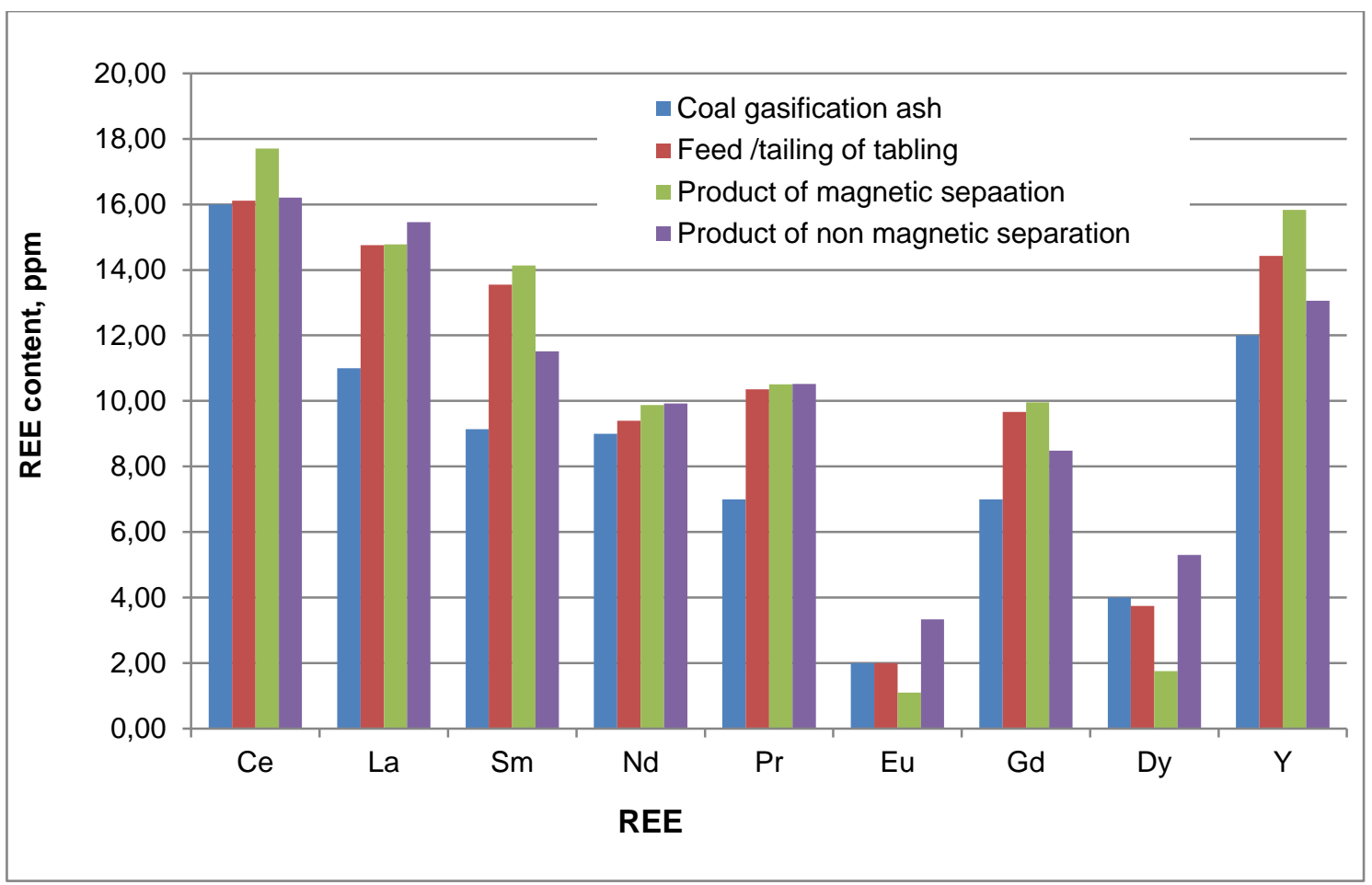

Figure 9. REE content in tabling tailing derived from the magnetic separation 
Table 10. REE content after magnetic treatments

\begin{tabular}{|c|c|c|c|c|c|c|}
\hline \multirow[b]{2}{*}{ No. } & \multirow[b]{2}{*}{ REE } & \multirow[b]{2}{*}{ Symbol } & \multicolumn{4}{|c|}{ REE Quantities (ppm) } \\
\hline & & & $\begin{array}{c}\text { Concentrate } \\
\text { magnetic }\end{array}$ & $\begin{array}{c}\text { Concentrate } \\
\text { Non-magnetic } \\
\end{array}$ & $\begin{array}{c}\text { Tailing } \\
\text { magnetic }\end{array}$ & $\begin{array}{c}\text { Tailing } \\
\text { Non-magnetic } \\
\end{array}$ \\
\hline 1 & Cerium & $\mathrm{Ce}$ & 34.2699 & 35.9641 & 17.7009 & 16.2125 \\
\hline 2 & Lanthanum & $\mathrm{La}$ & 28.1165 & 33.3242 & 14783 & 15.4624 \\
\hline 3 & Samarium & $\mathrm{Sm}$ & 21.1392 & 26.5158 & 14.1354 & 11.5156 \\
\hline 4 & Neodymium & $\mathrm{Nd}$ & 13.0177 & 20.8846 & 9.8781 & 9.9166 \\
\hline 5 & Praseodymium & $\operatorname{Pr}$ & 18.7672 & 25.6555 & 10.5069 & 10.5155 \\
\hline 6 & Europium & Eu & 4.1667 & 7.8723 & 1.0988 & 3.4398 \\
\hline 7 & Gadolinium & $\mathrm{Gd}$ & 15.333 & 28.507 & 9.9643 & 8.4802 \\
\hline 8 & Dysprosium & Dy & 15.4764 & 17.175 & 1.7676 & 5.2913 \\
\hline 9 & Yttrium & $\mathrm{Y}$ & 18.9711 & 21.3195 & 15.8346 & 13.0537 \\
\hline & Total REE & & 169.2577 & 217.218 & 95.6696 & 93.8876 \\
\hline
\end{tabular}

Table 11. The content of chemical compounds in non-magnetic concentrated materials

\begin{tabular}{llr}
\hline No. & $\begin{array}{l}\text { Chemical } \\
\text { compounds }\end{array}$ & \multicolumn{1}{l}{ wt\% } \\
\hline 1 & $\mathrm{La}_{2} \mathrm{O}_{3}$ & 0.039 \\
2 & $\mathrm{CeO}_{2}$ & 0.06 \\
3 & $\mathrm{Pr}_{6} \mathrm{O}_{11}$ & 0.008 \\
4 & $\mathrm{Nd}_{2} \mathrm{O}_{3}$ & 0.028 \\
5 & $\mathrm{Sm}_{2} \mathrm{O}_{3}$ & 0.005 \\
6 & $\mathrm{Gd}_{2} \mathrm{O}_{3}$ & $<0.001$ \\
7 & $\mathrm{Dy}_{2} \mathrm{O}_{3}$ & $<0.001$ \\
8 & $\mathrm{Ho}_{2} \mathrm{O}_{3}$ & $<0.001$ \\
9 & $\mathrm{Er}_{2} \mathrm{O}_{3}$ & $<0.001$ \\
10 & $\mathrm{Yb}_{2} \mathrm{O}_{3}$ & $<0.001$ \\
11 & $\mathrm{Lu}_{2} \mathrm{O}_{3}$ & $<0.001$ \\
\hline
\end{tabular}

\begin{tabular}{llr}
\hline No. & $\begin{array}{l}\text { Chemical } \\
\text { compounds }\end{array}$ & \multicolumn{1}{c}{ wt\% } \\
\hline 12 & $\mathrm{ThO}_{2}$ & 0.012 \\
13 & $\mathrm{U}_{3} \mathrm{O}_{8}$ & $<0.001$ \\
14 & $\mathrm{Y}_{2} \mathrm{O}_{3}$ & 0.034 \\
15 & $\mathrm{SiO}_{2}$ & 36.29 \\
16 & $\mathrm{Al}_{2} \mathrm{O}_{3}$ & 23.18 \\
17 & $\mathrm{Fe}_{2} \mathrm{O}_{3}$ & 4.67 \\
18 & $\mathrm{MnO}$ & 0.12 \\
19 & $\mathrm{MgO}$ & 1.52 \\
20 & $\mathrm{CaO}$ & 5.09 \\
21 & $\mathrm{~K}_{2} \mathrm{O}$ & 0.69 \\
22 & $\mathrm{TiO}_{2}$ & 1.38 \\
\hline
\end{tabular}

\begin{tabular}{llr}
\hline No. & $\begin{array}{l}\text { Chemical } \\
\text { compounds }\end{array}$ & \multicolumn{1}{c}{ wt\% } \\
\hline 23 & $\mathrm{P}_{2} \mathrm{O}_{5}$ & 0.29 \\
24 & $\mathrm{SO}_{3}$ & 0.002 \\
25 & $\mathrm{Cr}_{2} \mathrm{O}_{3}$ & 0.15 \\
26 & $\mathrm{HfO}_{2}$ & 0.019 \\
27 & $\mathrm{NiO}_{2}$ & 0.019 \\
28 & $\mathrm{SnO}_{2}$ & $<0.001$ \\
29 & $\mathrm{WO}_{3}$ & 0.003 \\
30 & $\mathrm{ZnO}_{31}$ & 0.019 \\
31 & $\mathrm{ZrO}_{2}$ & 0.47 \\
32 & $\mathrm{LOI}$ & 25.86 \\
\hline
\end{tabular}

According to Figure 8 and 9, the increase of the REE content in the non-magnetic separation of concentrate tabling is higher than that of the non-magnetic separation from tailing tabling. Table 10 and Figure 8 show escalation of the REE after magnetic separation from tabling concentrates. The elevated amounts of the REE content in both data generally show relatively small compare to feed (concentrate of tabling), except for Gd. The data also show the product of non-magnetic process increased the REE content even only in small quantity. It means that the efforts to increase the content is less effective. Table 10 and Figure 8 show the elevated amounts of REE from the tailing of the tabling process using a magnetic separator. Both data generally show a small increase of the REE content, except for Dy on magnetic separation and $Y$ on non-magnetic separation. These results reveal that the efforts to improve the content is still less effective. The low increase of the REE content is associated with its bearing mineral in the form of zirconium silicate. Silica is not affected by the magnetic field so the REE which is paramagnetic will be not attracted by the magnet.

The analysis results (Table 11) indicates a relatively high level of $\mathrm{LOI}$, amounting to $25.86 \%$. This shows that the gasification reaction was still not optimum. The high level of LOI came from the rest of carbon and corresponded with SEM analysis in Table 5 (Pomykała and Mazurkiewicz, 2015). The carbon residue in the coal gasification ash in Table 5 and 11 (in the form of LOI) is expected to be inert so it will reduce the recovery in the advanced stages of REE enrichment. One of them is the leaching stage. Silva et al. (2010) has analyzed various samples of some coal-fired power plants in Brazil showed that the LOI content of the ash is still high and it is directly related to the amount of unburned carbon. Efforts to reduce residual carbon can be done by burning the carbon at temperatures above $700{ }^{\circ} \mathrm{C}$ and under conditions of excess oxygen to give a proper combustion and leave only the ash. This burning stage is essentially also as an 
enrichment stage of the REE content of gasification ash.

\section{Advanced Improvement}

According to the analysis results in Table 11, efforts to increase the REE in coal gasification ash can be conducted as follows:

a. burning the ash at $700{ }^{\circ} \mathrm{C}$ to remove residual carbon or other LOI materials;

b. separating the material using a shaking table;

c. separating concentrates by a magnetic separation method,

d. pretreating non-magnetic material from magnetic separation process using $5 \mathrm{M}$ $\mathrm{NaOH}$ solution;

e. leaching with $1 \mathrm{M}$ nitric acid at a temperature of $80{ }^{\circ} \mathrm{C}$, followed by ion exchange.

\section{CONCLUSION}

The REE contents with the coal ash from gasification process at the fixed bed pilot plant Palimanan consist of cerium, lanthanum, samarium, neodymium, praseodymium, europium, gadolinium, dysprosium, and yttrium with its bearing mineral of zircon silicate $\left(\mathrm{ZrSiO}_{4}\right)$ and monazite-Ce $\left(\mathrm{CePO}_{4}\right)$.

The total REE content in the ash amounted to $77.85 \mathrm{ppm}$. Enrichment of REE levels by physical methods was conducted using a shaking table and the magnetic separator and can be increased up to 217 ppm. The shaking table was more effective to increase the concentration approximately two times in the flow of the concentrate, while magnetic separator provides insignificant results.

\section{ACKNOWLEDGEMENT}

The authors would like to thank the operators and laboratory analyst at the Center of Coal Technology Palimanan for their assistance to provide the coal ash samples use in this, the analysts in the Laboratory of Coal and Laboratory at the Research and Development Center for Mineral and Coal Technology, Bandung.

\section{REFERENCES}

Elliott, M. A. (1981) Chemistry of coal utilization : Second supplementary volume. 1st Ed. New York: John Wiley \& Sons.

Endang Suwargi, Pardiarto, B. and Ishlah, T. (2010) "Potensi logam tanah jarang di Indonesia," Buletin Sumber Daya Geolog, 5(3), pp. 131-140.

Fitriana, I., Sugiyono, A., Anindhita, F., Wahid, L. O. M. A. and Adiarso (2017) Indonesia energy outlook 2017: Clean energy technology development initiatives. Jakarta: BPPT-Press. Available at: https://www.bppt.go.id/outlookenergi/bppt-outlook-energi-indonesia2017/download.

Ginster, M. and Matjie, R. H. (2005) "Beneficial utilization of Sasol coal gasification ash," in 2005 World of Coal Ash (WOCA). 2005 World ash (WOCA). Available at: http://www.flyash.info/2005/94gin.pdf.

Hosseini, S. (2015) Behavior of inorganic matters during coal gasification. University of Alberta. Available at: https://era.library.ualberta.ca/items/1cc4 8ba8-6c7a-4962-ac07-0b476dd18b2f.

Hower, J., Granite, E., Mayfield, D., Lewis, A. and Finkelman, R. (2016) "Notes on contributions to the science of rare earth element enrichment in coal and coal combustion byproducts," Minerals, 6(2), p. 32. doi: 10.3390/min6020032.

Long, K. R., Gosen, B. S. Van, Foley, N. K. and Cordier, D. (2018) The geology of rare earth elements, www.geology.com. Available at: https://geology.com/usgs/ree-geology/ (Accessed: June 4, 2018).

Pomykała, R. and Mazurkiewicz, M. (2015) "Properties of coal gasification wastes essential to determining their impact on the environment," Polish Journal of Environmental Studies, 24, pp. 21472155. doi: $10.15244 /$ pjoes/42370.

Rodliyah, I. (2017) "Pengolahan mineral monasit," in Wahyudi, T., Handayani, S., and Jafril (eds.) Logam Tanah Jarang: Minyak Bumi Abad ke-21. Jakarta: LIPI Press, pp. 143-160.

Roth, E., Macala, M., Lin, R., Bank, T., Thompson, R., Howard, B., Soong, Y. and Granite, E. (2017) "Distributions and extraction of rare earth elements from coal and coal by-products," in 2017 World of Coal Ash 
Conference. Lexington: World of Coal Ash (WOCA). Available at: http://www.flyash.info/2017/113-Rothwoca2017p.pdf.

Sahoo, P. K., Kim, K., Powell, M. A. and Equeenuddin, S. M. (2016) "Recovery of metals and other beneficial products from coal fly ash: A sustainable approach for fly ash management," International Journal of Coal Science \& Technology, 3(3), pp. 267-283. doi: 10.1007/s40789016-0141-2.

Silva, L., Ward, C., Hower, J., Izquierdo, M., Waanders, F., Oliveira, M., Li, Z., Hatch, R. and Querol, X. (2010) "Mineralogy and leaching characteristics of coal ash from a major Brazilian power plant," Coal Combustion and Gasification Products, 2(1), pp. 51-65. doi: 10.4177/CCGP-D10-00005.1.

Sodikin, I., Sulistyohadi, F., Yaskuri, D., Nurhadi, Sofaety, Y., Umar, D. F., Ningrum, N. S., Andriansyah, M. A., Monika, I., Diniyati, D., Yusnanto, Saputra, R., Ropik, Setiawan, L., Phiciato, Irawan, C., Rianda, S., Sirait, J. K., Syarifah, T. S., Elvan, R. S., Arifin, R. S., Ujat, Widodo, Supriatna, W., Santosa, S. G., Irawan, W., Spadia, M. D., Hertantiyo, D., Susanti, I., Hidayat, H. and Mujib (2016) Pengembangan teknologi gasifikasi batubara untuk bahan bakar. Bandung: Puslitbang tekMIRA.

Speight, J. G. (2013) The chemistry and technology of coal. 3rd Ed. CRC Press.

Suganal (2017) "Kandungan unsur logam tanah jarang pada abu dasar (bottom ash) dari Pembangkit Listrik Tenaga Uap (PLTU) berbahan bakar batubara," in Prosiding Kimia Nasional XX: Kimia dalam Pembangunan. Yogyakarta: Jasakiai, pp. 81-88. Available at: http://reponkm.batan.go.id/1180/1/016.pdf.
Suganal, Suratman and Kusnawan (2016) "Identifikasi sumber daya mineral logam pembawa unsur logam tanah jarang (rare-earth elements REE) di wilayah Purbalingga," in Prosiding Seminar Nasional XIX: Kimia dalam Pembangunan. Yogyakarta: Jasakiai, pp. 401-408.

Suganal, Umar, D. F. and Mamby, H. E. (2018) "Identifikasi keterdapatan unsur logam tanah jarang dalam abu batubara Pusat Listrik Tenaga Uap Ombilin, Sumatera Barat," Jurnal Teknologi Mineral dan Batubara, 14(2), pp. 111-125. doi: 10.30556/jtmb.Vol14.No2.2018.395.

Suprapto, S. (2009) "Penanganan limbah pembakaran batubara pada pabrik tekstil studi kasus pabrik tekstil di Kabupaten Bandung," Jurnal Teknologi Mineral dan Batubara, 5(2), pp. 19-31. Available at:

https://jurnal.tekmira.esdm.go.id/index.p $\mathrm{hp} / \mathrm{minerba/article/view/904.}$

Ye, I., Oh, J. and Ryu, C. (2015) "Effects of design/operating parameters and physical properties on slag thickness and heat transfer during coal gasification," Energies, 8(5), pp. 33703385. doi: 10.3390/en8053370.

Yermagambet, B. T., Becturganov, N. S., Nabiyev, M. A., Nurgaliev, N. U. and Kassenova, Z. M. (2016) "Coal gasification and gas obtaining for synthesis of the motor fuels," in Litvinenko, V. (ed.) XVIII International Coal Preparation Congress. Cham: Springer International Publishing, pp. 573-578. doi: 10.1007/978-3-319-40943688 .

Zhang, W., Groppo, J. and Honaker, R. (2015) "Ash beneficiation for REE recovery," in 2015 World of Coal Ash (WOCA) Conference. Nasvhille: World of Coal Ash (WOCA), pp. 1-11. Available at: http://www.flyash.info/2015/194-Groppo2015.pdf. 
